\title{
POLITIK HUKUM PEMBENTUKAN UNDANG-UNDANG PERLINDUNGAN ANAK UNTUK MEWUJUDKAN PERLINDUNGAN ANAK YANG BERKELANJUTAN
}

\author{
Laurensius Arliman S \\ Dosen STIH Padang \\ Email: laurensiusarliman@gmail.com
}

\begin{abstract}
Child protection in Indonesia is closely linked to Indonesian legal politics that gave birth to Indonesia's legal system. The legal political struggle in establishing child protection arrangements in Indonesia, is the impact of providing legal certainty to child protection. In today's protection is very sad. This paper will discuss about: 1) how the development of legal politics at this time? 2) how does legal political analysis affect changes to child protection legislation? 3) how is the formation of the second amendment of child protection law number 17 of 2016? The approach method used is normative legal research. Political law is always evolving in accordance with the interests of the legislature and the interests of society. The legal politics of child protection in Indonesia as a positive legal system or ius contituendum and the intended law or ius contitium applicable and which will prevail in the present and future. Therefore, the legal system of child protection is formed as a consequence of the application of Indonesian legal politics. The Child Protection Act was established as a result of the Political Law of Government, which in this case explains that the legal politics is part of the jurisprudence studying the change of ius constitutum into ius constituendum to fulfill the life of society change.
\end{abstract}

Keywords: Political Law; Child protection; Suistanable.

\begin{abstract}
Abstrak
Perlindungan anak di Indonesia, berkaitan erat dengan politik hukum Indonesia yang melahirkan sistem hukum Indonesia. Pergulatan politik hukum di dalam pembentukan pengaturan perlindungan anak di Indonesia, adalah dampak dari untuk memberi kepastian hukum terhadap perlindungan anak. Pada hari ini perlindungan terhadap sangat menyedihkan. Tulisan ini akan membahas mengenai: 1) bagaimana perkembangan politik hukum pada saat ini? 2) bagaimana analisis politik hukum mempengaruhi perubahan undang-undang perlindungan anak? 3) bagaimana pembentukan perubahan kedua undang-undang perlindungan anak nomor 17 tahun 2016? Metode pendekatan yang dipakai adalah penelitian hukum normatif. Politik hukum selalu berkembang sesuai dengan kepentingan pihak legislatif dan kepentingan masyarakat. Politik hukum perlindungan anak di Indonesia sebagai sistem hukum positif atau ius contituendum dan hukum yang diimpikan atau ius contitium yang berlaku dan yang akan berlaku pada saat sekarang dan pada masa akan datang. Sebab, sistem hukum perlindungan anak tersebut terbentuk sebagai konsekuensi penerapan politik hukum Indonesia. UndangUndang Perlindungan Anak dibentuk sebagai hasil dari Politik Hukum Pemerintahan, di mana hal ini menjelaskan bahwa politik hukum bagian dari ilmu hukum yang mengkaji perubahan ius constitutum menjadi ius constituendum untuk memenuhi kehidupan perubahan masyarakat.
\end{abstract}

Kata kunci: Politik Hukum; Perlindungan Anak; Berkelanjutan. 


\section{A. PENDAHULUAN}

\section{Latar Belakang}

Undang-undang merupakan salah satu bagian dari sistem hukum. Karenanya, proses pembentukan undang-undang akan sangat dipengaruhi oleh sistem hukum yang dianut oleh negara tempat undang-undang itu dibentuk. Sehingga, untuk mengkaji pembentukan undang-undang secara komprehensif, haruslah dimulai dengan mengkaji sistem hukum itu sendiri. ${ }^{1}$

Hukum itu bukan merupakan tujuan, akan tetapi hanya merupakan jembatan, yang akan harus membawa kita kepada ide yang dicita-citakan. ${ }^{2}$ Apabila kita berpegangan pada apa yang dikatakan di atas, maka kita perlu terlebih dahulu mengetahui masyarakat yang bagaimana yang dicita-citakan oleh rakyat Indonesia. Baru setelah diketahui masyarakat yang bagaimana yang dicita-citakan oleh bangsa Indonesia, dapatlah dicari sistem hukum yang bagaimana yang dapat membawa rakyat kita ke arah masyarakat yang dicit-citakan itu, dan politik hukum yang bagaimana yang dapat menciptakan sistem hukum nasional yang dikehendaki itu. Yuliandri ${ }^{3}$ menyebutkan bahwa paket undang-undang dalam bidang politik, dapat dijadikan salah satu tolak ukur untuk melihat bangunan sistem kelembagaan negara yang dipakai.

Namun demikian, politik hukum itu tidak terlepas dari pada realita sosial dan tradisional yang terdapat di negara kita, dan di lain pihak, sebagai salah satu anggota masyarakat dunia, politik hukum Indonesia tidak terlepas pula dari realita dan politik hukum internasional. Dengan demikian faktor-faktor yang akan menentukan politik hukum nasional itu tidaklah semata-mata ditentukan oleh apa yang kita cita-citakan atau tergantung pada kehendak pembentuk hukum, praktisi atau para teoretisi belaka, akan tetapi ikut ditentukan oleh perkembangan hukum di lain-lain negara, serta perkembangan internasional. Dengan kata lain perkataan ada faktor-faktor di luar jangkauan bangsa kita, yang ikut menentukan politik hukum masa kini dan di masa yang akan datang. ${ }^{4}$ Hal ini berlaku pula pada regulasi dan dinamika perlindungan anak sebagai generasi penerus bangsa Indonesia.

Anak pada dasarnya adalah amanah sekaligus karunia Tuhan Yang Maha Esa, yang senantiasa harus dijaga karena dalam dirinya melekat harkat, martabat dan hak-hak

Yuliandri, Asas-Asas Pembentukan Peraturan Perundang-Undangan Yang Baik, Gagasan Pembentukan UndangUndang Berkelanjutan, Jakarta, Rajawali Press, 2010, Hlm. 31.

Sunaryati Hartono, Apakah The Rule of Law Itu? Alumni, Bandung, 1976, Hlm. 17.

Yuliandri, Membentuk Undang-Undang Berkelanjutan, Jurnal Konstitusi Mahkamah Konstitusi Bekerjasama dengan Pusako, Volume 2, Nomor 2, 2009, Hlm. 10.

4 Sunaryati Hartono, Politik Hukum Menuju Satu Sistem Hukum Nasional, Bandung, Alumni, 1991,Hlm. 1-2. 
sebagai manusia yang harus dijunjung tinggi. Anak dilahirkan merdeka, tidak boleh dilenyapkan atau dihilangkan, kemerdekaan anak harus dilindungi dan diperluas dalam hal mendapatkan hak atas hidup dan hak perlindungan baik dari orang tua, keluarga, masyarakat, bangsa dan negara. ${ }^{5}$ Oleh karena itu tidak ada setiap manusia atau pihak lain yang boleh merampas hak tersebut, karena hak asasi anak tersebut merupakan bagian dari hak asasi manusia (HAM) yang mendapat jaminan dan perlindungan hukum secara internasional maupun hukum nasional.

Atas dasar tersebut pemerintah berupaya melakukan pemberian perlindungan terhadap anak. Perlindungan hukum bagi anak dapat diartikan sebagai upaya perlindungn bagi hukum terhadap berbagai kebebasan dan hak asasi anak (fundamental rights and freedoms of children) serta berbagai kepentingan yang berhubungan dengan kesejahteraan anak. Oleh karenanya penghargaan akan hak-hak yang melekat pada anak tetaplah harus dikedepankan dalam segala waktu, tempat maupun personality pengedepanan prinsipprinsip non-diskriminasi, kepentingan terbaik untuk anak, dan hak untuk hidup kelansungan dan perkembangan, penghargaan terhadap pendapat anak, tidaklah ditawartawar lagi harus senantiasa menyertai anak tersebut.

Pada saat ini kita sedang menghadapi permasalah besar tentang anak, bukan saja dalam jumlah tetapi juga karena permasalahan yang semakin kompleks. Dahulu kita mengenal permasalahan anak hanya berkisar pada ketelantaran yang disebabkan karena ketidakmampuan untuk memenuhi kebutuhan fisik saja, sedang kebutuhan yang bersifat mental spritual dan sosial masih dapat dipenuhi oleh orang tua manapun atau masyarakat dilingkungannya. Seiring dengan perubahan-perubahan yang erjadi terutama adanya arus globalisasi yang selalu membawa konsekuensi logis positif dan negatif, maka tidaklah mengherankan manakala permasalahan anak saat ini telah menjadi begitu kompleks dan rumit.

Anak telah menjadi sasaran kepentingan bagi banyak kalangan, termasuk untuk tujuan komersial yang merugikan kepentingan terbaik bagi anak. Betapa saat ini telah terjadi semacam jaringan yang memanfaatkan anak objeknya. Anak dijadikan objek untuk diperjualbelikan, objek kekerasan, menjadi alat oleh orang dewasa tertentu untuk mencari nafkah dijalan-jalan sebagai anak jalana, dan sebagainya. Perlakuan kekerasan terhadap anak itu seringkali justru terjadi dilingkungan sekitar anak itu sendiri, dimana seharusnya anak memperoleh perlindungan. Lihat saja pada ini kasus kelalaian terhadap perlindungan

R. Abdussalam, Hukum Perlindungan Anak, Jakarta, PTIK, 2012, Hlm. 10. 
anak: 1) semakin meningkatnya anak yang disuruh orangtuanya untuk bekerja di jalanan; 2) anak yang dipaksa bekerja untuk memenuhi kebutuhan keluarga; 3) kekerasan seksual terhadap anak; 4) anak diperjualbelikan (eksploitasi) untuk pemuas seks dan kasus lainnya yang tidak menguntungkan anak. Itulah gambaran yang kurang menggemberikan bagi potret anak di Indonesia, pada masa ini.

Akibat semakin memprihatikannya perlindungan anak di Indonesia, teruatama dengan meomentum banyaknya anak-anak yang menjadi korban dari kekerasan seksual di Indoesia, maka Presiden Jokowi mengeluarkan Peraturan Pemerintah Pengganti UndnagUndang atas Perubahan Kedua Undang-Undang Nomor 23 Tahun 2002 tentang Perlindungan Anak atau yang lebih dikenal tentang Perppu Perlindungan Anak, dan akhirnya dijadikan undang-undang oleh Dewan Perwakilan Rakyat Daerah Republik Indonesia (DPR RI) menjadi Undang-Undang Republik Indonesia Nomor 17 Tahun 2016 Tentang Penetapan Peraturan Pemerintah Pengganti Undang-Undang Nomor 1 Tahun 2016 Tentang Perubahan Kedua Atas Undang-Undang Nomor 23 Tahun 2002 Tentang Perlindungan Anak Menjadi Undang-Undang (UU 17/2016) pada tanggal 12 Oktober 2016 pada sidang rapat Paripurna DPR RI tanpa ada pengubahan isi.

Tentu perubahan-perubahan ini dipengaruhi oleh politik hukum dalam dinamika kenegaraan dan pemerintah Indonesia. Politik hukum perlindungan anak ini sebenarnya diharapkan mewujudkan perlindungan anak yang berkelanjutan dan memberikan rasa nyaman bagi kebutuhan perkembangan anak menjadi generasi penerus bangsa Indonesia kelak.

\section{Rumusan Masalah}

a. Apa itu politik hukum dalam perkembangan ilmu hukum?

b. Bagaimana analisis politik hukum mempengaruhi perubahan undang-undang perlindungan anak?

c. Bagaimana pembentukan perubahan kedua undang-undang perlindungan anak nomor 17 tahun 2016 ?

\section{Metode Penelitian}

Penelitian hukum yang dilaksanakan merupakan penelitian hukum normatif dengan metode pendekatan yuridis normatif yang menitik beratkan penggunaan bahan atau meteri penelitian data sekunder dengan di dukung oleh data kepustakaan. Di samping itu, penelitian ini juga menggunakan pendekatan perundang-undangan (statute approach), pendekatan historis (historical approach), dan pendekatan perbandingan (comparative 
approach). ${ }^{6}$ Dlihat dari spesifikasinya, penelitian ini termasuk deskriptif analitis yaitu penelitian yang menggabarkan dan menganalisis permasalahan yang berhubungan dengan kedaulatan negara di bidang HAM. Dalam penelitian ini, proses perolehan data untuk menunjang hasil penelitian dilakukan melalui tahapan studi kepustkaan (library research) dengan menggunakan data sekunder, yaitu mencoba untuk menemukan buku-buku, konsep-konsep, teori-teori dan pendapat para ahli serta penemuan yang berhubungan erat dengan pokok permasalahan yang akan diteliti.

\section{B. PEMBAHASAN}

\section{Politik Hukum Di Dalam Perkembangan Ilmu Hukum}

Fungsi dan peran hukum sangat dipengaruhi dan kerapkali diintervensi oleh kekuatan politik. Di Indonesia konfigurasi politik berkembang melalui tolak-tarik antara yang demokratis dan otoritarian, sedangkan karakter produk hukum mengikutinya dalam tolak-tarik antara yang responsif dan konservatif. Sementara itu, untuk membangun tertib tata hukum dan meminimalisirkan pengaruh politik, judicial review sebenarnya dapat dijadikan alat kontrol yang baik. Tetapi ketentuan-ketentuan judicial review di dalam perbagi peraturan perundang-undangan ternyata mengandung pula kekacauan teoritis sehingga tidak dapat dioperasionalkan. ${ }^{7}$

Berdasarkan kaidah-kaidah penuntut tersebut, sebenarnya telah terdapat pedoman yang kokoh untuk menyelesaikan persoalan-persoalan politik dan hukum atau konsistensi produk hukum yang dipertentangkan di tengah-tengah masyarakat. ${ }^{8}$ Pengaturan di dalam sebuah undang-undang tentang pelaksanaan berbagai hak-hak politik itu memang cenderung korup karena semua undang-undang yang lahir selalu bersifat positivistinstrumentalistik, dalam arti selalu berisi tentang pembenaran atau justifikasi atas kehendak-kehendak politik dan program pemerintah. ${ }^{9}$

Atas hal tersebut maka jelas politik dan hukum saling kait mengkaitkan menjadi suatu hal yang bernama politik hukum dalam pandangan dan perkembangan ilmu hukum. Politik hukum adalah legal policy atau arah hukum yang akan diberlakukan oleh negara untuk mencapai tujuan negara yang bentuknya dapat berupa pembuatan hukum baru

\footnotetext{
6 Johnny Ibrahim, Teori dan Metodologi Penelitian Hukum Normatif, Malang, Bayu Media Publishing, 2006, Hlm. 302.

7 Moh. Machfud MD, Pergulatan Politik dan Hukum Di Indonesia, Jakarta, Gramedia, 1999, Hlm. 1.

8 Moh. Machfud MD, Perdebatan Hukum Tata Negara Pasca Amandemen Konstitusi, Jakarta, Rajawali Press, 2010, Hlm. 11.

9 Moh. Machfud MD, Demokrasi Dan Konstitusi Di Indonesia, Studi Tentang Interaksi Politik Dan Kehidupan Ketatanegaraan, Jakarta, Rineka Cipta, 2003, Hlm. 170.
} 
penggantian hukum lama. Dalam arti yang seperti ini politik hukum harus berpijak pada tujuan negara dan sistem hukum yang berlaku di negara yang bersangkutan yang dalam konteks Indonesia, dengan tujuan dan sistem itu terkandung di dalam pembukaan UUD 1945, khususnya Pancasila, yang melahirkan kaidah-kaidah penuntun hukum. Program legislasi nasional (Prolegnas) dapat disebut sebagai contoh tentang politik hukum, tetapi ia hanya bagian dari ilmu politik hukum. ${ }^{10}$

Sementara itu, ilmu atau studi politik hukum bukan hanya menyangkut policy atau arah resmi tentang hukum yang akan diberlakukan melainkan menyangkut juga berbagai hal yang terkait dengan arah resmi itu, misalnya politik apa yang melatarbelakangi, budaya hukum apa yang melingkupi, dan problema penegakan macam apa yang dihadapi. Berbeda dari politik hukum, ilmu politik hukum itu membedah semua unsur dalam sistem hukum yang unsur-unsur utamanya dikelompokkan menjadi tiga unsur besar, yaitu materi hukum, struktur hukum, dan budaya hukum. Pemikiran seperti ini sejalan juga dengan teori yang digambarkan di atas tentang Pohon Ilmiah Hukum di mana ilmu hukum tidak hanya di pandang sebagai norma-norma atau hukum positif. Dalam hal ini, ilmu politik hukum bukan hanya mencakup politik hukum dalam arti sebagai arah resmi negara untuk memberlakukan atau tidak memberlakukan hukum guna mencapai tujuan negara, melainkan ia juga mencakup latar belakang dan lingkungan yang mempengaruhi serta berbagai persoalan yang dihadapi dalam upaya menegakkannya. ${ }^{11}$

Oleh Moh. Machfud MD membagi studi politik hukum ke dalam tiga kelompok. Pertama, arah resmi tentang hukum yang akan diberlakukan atau tidak akan diberlakukan (legal policy) guna mencapai tujuan negara yang mencakup penggantian hukum lama dan pembentukan hukum-hukum yang baru sama sekali. Kedua, latar belakang politik dan subsistem kemasyarakatan lainya di balik lahirnya hukum, termasuk arah resmi tentang hukum yang akan atau tidak akan diberlakukan. Ketiga, persoalan-persoalan di sekitar penegakan hukum, terutama implementasi atas politik hukum yang telah digariskan. ${ }^{12}$

Atas hal tersebut terlihat bahwa dalam hubungan tolak tarik antara politik dan hukum, maka huukumlah yang terpengaruh politik, karena subsistem politik memiliki konsentrasi energi yang lebih besar daripada hukum. Sehingga jika harus berhadapan dengan politik, maka hukum berada dalam kedudukan yang lebih lemah dengan politik, maka hukum berada dalam kedudukan yang lebih lemah. Untuk memahami sistem hukum

\footnotetext{
10 Moh. Machfud MD, Membangun Politik Hukum, Menegakkan Konstitusi, Jakarta, Rajawali Press, 2011 , Hlm. 5.

11 Ibid, Hlm. 5-6.

12 Ibid, Hlm. 6.
} 
di tengah-tengah transformasi politik harus diamati dari bawah dan dilihat peran sosial politik apa yang diberikan kepadanya. Karena lebih kuatnya konsentrasi energi politik, maka menjadi beralasan adanya konstatasi bahwa kerapkali otonomi hukum di Indonesia ini diintervensi oleh politik, bukan hanya dalam proses pembuatanya, tetapi juga dalam implementasinya. ${ }^{13}$

Dengan menggunakan ausmsi dasar bahwa hukum sebagai produk politik, maka politik akan sangat menentukan hukum, sehingga meletakkan politik sebagai variable bebas dan hukum sebagai variabel terpengaruh. Dengan pernyataan hipotesis yang lebih spesifik dapat dikemukakan bahwa konfigurasi poltik suatu negara akan melahirkan karakter produk hukum tertentu di negara teresebut, Di dalam negara yang konfigurasi politiknya demokratis, maka produk hukumnya berkarakter responsif atau populistik, sedangkan di negara yang konfigurasi politiknya otoriter, maka produk hukumnya berkaraker ortodoks/konservatiflelitis. Perubahan konfigurasi politik dari otoriter ke demokratis atau sebaliknya berimplikasi pada perubahan karakter produk peraturan hukum. ${ }^{14}$

\section{Analisis Politik Hukum Mempengaruhi Perubahan Undang-Undang Perlindungan} Anak

Politik dan hukum dapat diibaratkan sebagai dua sisi dari satu mata uang logam. Pengibaratan itu memberi makna bahwa hubungan antara politik dan hukum sangatlah erat. Bila kita membahas atau membicarakan penyelenggaraan negara atau pemerintahan baik di tingkat pusat maupun daerah maka politik dan hukum selalu mendapat tempat yang utama. Pada masa Orde Baru bidang hukum selalu disatukan dengan bidang politik atau pembangunan hukum menjadi bagian dari pembangunan politik. Hal tersebut bukan berarti bidang politik dan hukum atau masing-masing bidang tersebut tidak erat kaitannya dengan bidang-bidang lainnya seperti ekonomi, sosial budaya, hankam, luar negeri dan sebagainya. Tetapi hubungan hukum dan politik melebihi keeratan hubungan kedua bidang tersebut dengan bidang-bidang lainnya itu. Hukum selalu menjadi sarana dari politik untuk mempengaruhi, membangun dan mengembangkan bidang-bidang lainnya itu. Dalam hal inilah berlaku tesis bahwa hukum adalah putusan politik (law is a political decision). ${ }^{15}$

\footnotetext{
13 Moh. Machfud MD, Politik Hukum di Indonesia, Jakarta, Rajawali Press, 2011, Hlm. 20.

14 Ibid, Hlm. 22.

15 Bintan Regen Saragih, Politik Hukum, Bandung, CV. Utomo, 2006, Hlm. 5.
} 
Dalam hubungan dengan pembaharuan hukum, Mochtar Kusumaatmadja mengatakan bahwa suatu konsepsi yang erat hubungannya dengan usaha pembaharuan hukum yakni hukum sebagai alat pembaharuan masyarakat atau sarana pembaharuan masyarakat. Konsepsi ini mirip dengan lal as a tool of social enginering yang di negara barat pertama kali dipopulerkan oleh apa yang dikenal sebagai aliran pragmatic legal realisme. ${ }^{16}$ Dalam hubungan dengan pendapat Mochtar di atas, kita sudah berbicara mengenai fungsi hukum atau sering juga disebut sebagai tujuan hukum, secara umum fungsi hukum ialah: a) memelihara kepastian hukum; b) menjamin kepastian hukum; c) sebagai pengayom masyarakat; d) pelerai perselisihan-perselisihan dalam masyarakat; e) membagi kekuasaan dan kewenagan dalam negara dan pemerintahan; dan menegakan keadilan. ${ }^{17}$

Politik hukum kehadiran Undang-Undang Perlindungan anak jika dilihat dari aspek tujuan dari kehadiran Undang-Undang tersebut adalah untuk memberikan penghargaan terhadap pendapat anak, menolak sikap diskriminasi terhadap anak; memprioritaskan kepentingan terbaik bagi anak; serta menciptakan suasana nyaman bagi kehidupan dan perkembangan anak jika terkait dengan anak sebagai seorang tersangka.

Maksud dari politik hukum perlindungan anak disini adalah hukum positif, perlindungan anak, yaitu hukum yang berlaku pada waktu sekarang di Indonesia, sesuai dengan asas pertingkatan (hirarki) hukum itu sendiri, atau dengan istilah yang diberikan Logeman, sebagai hukum yang disini dan kini. ${ }^{18}$ Sedang hukum poistif itu menurut Bintan Raden Saragih adalah hukum yang dibuat atau ditetapkan oleh negara melalui lembaga negara atau pejabat yang diberi wewenang untuk menetapkannya. ${ }^{19}$ Apabila pebentukan hukum positif tersebut dihubungkan dengan hirarki pembentukan perundang-undangan, maka akan berkaitan dengan asas-asas pembentukan peratiran perundang-undangan juga.

Asas-asas pembentukan peraturan perundang-undangan, merupakan pembicaraan yang erat hubungannya dengan politik hukum pembentukan peraturan perundangundangan. Asas-asas pembentukan peraturan perundang-undnagan merupakan suatu pedoman atau suatu rambu-rambu yang harus diikuti oleh pembentuk undang-undang (DPR, Presiden, dan DPD) dalm pembentukan peraturan perundang-undangan. Dimana rujukannya adalah Pancasila, sebagai sumber hukum dan Undang-Undang Dasar Negara

\footnotetext{
16 Mochtar Kusumaatmadja, Hukum, Masyarakat dan Pembinaan Hukum Nasional, Bandung, Bina Cipta, 1986, Hlm. $8-9$.

17 Bintan Regen Saragih, Op.cit, Hlm. 13.

18 J.H.A Logeman, Over de Theoroe Van Een Stellig Staatsrecht, Universitas Pers Leiden, (Penerjemah) Makkatutu, Tentang Teori Suatu Hukum Tata Negara Positif, 1976, Jakarta, Penerbit Ichtiar Baru-Van Hoeve, 1948, Hlm. 31.

19 Bintan Regen Saragih, Op.cit, Hlm. 17.
} 
Republik Indoensia Tahun 1945 (UUD 1945) ${ }^{20}$ sebagai dasar hukum, merupakan pedoman, batu uji, atau pemandu dan alat filterisasi sekaligus menjadi tujuan dari semua politik hukum nasional, pada dasarnya mutatis mutandis bagi politik pembentukan hukum melalui pembentukan peraturan perundang-undangan. ${ }^{21}$

Politik hukum pembentukan pengaturan perlindungan anak sebenarnya telah dijelaskan dalam Alinea IV Pembukaan UUD 1945, yang mengamanatkan bahwa negara akan melindungi segenap bangsa Indonesia dan mewujdukan keadilan sosial bagi seluruh rakyat Indonesia, yang mengandung makna akan dijaminnya perlindungan seluruh rakyat tanpa mengenal usia termasuk perlindungan terhadap anak. Selanjutnya pernyataan tersebut dituangkan dalam BAB X A Pasal 28 B ayat (2) dan BAB XIV Pasal 34 yang menyatakan setiap anak berhak atas kelangsungan hidup, tumbuh dan berkembang serta berhak atas perlindungan dari kekerasan dan diskriminasi, kemudian fakir miskin dan anak-anak terlantar dipelihara oleh negara.

Bangsa Indonesia dalam mengisi dinamika kehidupan dan politik hukum perlindungan anak, telah mengupayakan program untuk mewujudkan perlindungan terhadap anak, baik dari segi hukum maupun kebutuhan fisik, mental dan sosial. Namun demikian, hasilnya masih belum memenuhi harapan masyarakat, terlebih pada situasi sulit seperti saat ini. Masih banyak anak-anak terpaksa bekerja di terminal dan jalanan tanpa mendapatkan kesempatan istirahat yang cukup, demikian pula yang bekerja menjadi pemulung, pengemis maupun penjaja seks dan bahkan terjadinya bayi sewaan. ${ }^{22}$

Fraksi TNI/Polri dalam Risalah Perundangan-Undangan Pembentukan UndangUndang Nomor 23 Tahun 2002 Tentang Perlindungan Anak menyambut baik usul inisiatif rancangan Undang-Undang Perlindungan Anak, dimana Fraksi TNI/Polri menyampaikan beberapa pokok-pokok pikiran sebagai berikut: a) Rancangan Undang-Undang Perlindungan Anak ini harus dapat menjamin hak dan kewajiban anak untuk berkembang sebagai generasi bangsa yang berkualitas, mampu bersaing dan dapat menciptakan masa depan yang baik; b) secara umum pasal-pasalnya harus dapat diimplementasikan secara tegas, baik hak maupun kewajiban masing-masing pihak dalam menjamin kewajiban dan

20 Walaupun amandemen terhadap UUD 1945 sejak tahun 1999 sampai 2002, telah membawa implikasi pada sistem ketatanegaraan Indonesia. Tetapi di balik konsekuensi perubahan dimaksud, secara substansi juga menimbulkan masalah. Apabila dilihat dari perumusan norma pada pasal-pasal UUD 1945 terdapat beberapa bahasa, yang akhirnya tidak mencerminkan kualitas dari konstitusi. Lihat dalam: Yuliandri, Kerancuan Perumusan Norma Konstitusi, di dalam: Kelompok DPD RI, Jalan Berliku Amandemen Komprhensif (Dari Pakar, Politisi, Hingga Selebriti), Jakarta, Kelompok DPD RI, 2009, Hlm. 76.

21 Otong Rosadi dan Andi Desmon, Studi Politik Hukum, Suatu Optik Ilmu Hukum, Semarang, Thafa Media, 2012, Hlm. 116.

22 Risalah Perundangan-Undangan Pembentukan Undang-Undang Nomor 23 Tahun 2002 Tentang Perlindungan Anak, Hlm. 187. 
perlindungan terhadap perkembangan anak; c) rancangan Undang-Undang Perlindungan Anak ini agar dikorelesikan dengan peraturan perundang-undangan lainnya sehingga saling mendukung dan memperkuat satu dengan lainnya.

Selain itu pandangan Fraksi TNI/Polri menjelaskan bahwa: a) prosedur memperoleh perlindungan secara jelas, terutama berkaitan dengan tindak pidana; b) perlindungan bagi anak yang mengidap atau terkena HIV/AIDS akibat penggunaan Narkoba dan seks bebas; c) perlindungan terhadap kekerasan informasi yang disajikan oleh media massa baik tulis maupun elektronik; d) perlindungan terhadap eksploitasi anak yang kenyataannya banyak menjadi pekerja dibidang formal maupun informal; e) perlindungan bagi anak miskin yang tidak mampu mengikuti pendidikan terutama dalam memenuhi ketentuan wajib belajar; f) perlindungan terhadap eksploitasi politik, seperti pelibatan anak-anak dalam kampanye pemilihan umum dan unjuk rasa serta g) perlindungan bagi anak terhadap kekerasan yang kurang wajar dalam keluarga.

Hal ini sependapat dengan pandangan dari Fraksi Partai Demokrasi Indonesia Perjuangan DPR-RI yang menyatakan bahwa: Pertama, penyusunan sebuah undangundang haruslah mempunyai landasan normatif yang berarti bahwa undnag-undang tersebut mempunyai norma yang ada kaitan dengan norma di atasnya lebih tinggi, dimana norma-norma yang terkandung dalam undang-undang tersebut mendasarkan dirinya. Ada kaedah-kaedah normatif yang diusulkan dalam usulan rancangan Undang-Undang Perlindungan Anak mempunyai landasan formal yuridis sebagaimana dalam konstitusi kita, dan hal ini sebenarnya bersumber pada tujuan negara kita, dimana di dalamnya terkandung upaya untuk melindungi segenap bangsa dan seluruh tumpah darah Indonesia, memajukan kesejahteraan umum dan mencerdaskan kehidupan bangsa.

Kedua, argumentasi sosiologis yang telah disebutkan oleh pengusul dalam penjelasan tentang usul rancangan Undang-Undang Perlindungan Anak ini. Usul ini telah mempunyai landasan sosiologis yang merupayakan sumber hukum materil dari proses pembuatan hukum. Ketiga, alasan filosofis pun telah dikemukakan dengan melihat anak sebagai harapan bangsa yang mempunyai zona tentang hidupnya sendiri, dan orang tua mempunyai kewajiban untuk menyediakan ruang bagi mereka tumbuh dan berkembang. Keempat, adanya tanggapan terhadap tuntutan untuk membela kepentingan hak asasi manusia (HAM) secara umum. Sehingga usul rancangan Undang-Undang Perlindungan Anak ini sungguh akomodatif terhadap tuntutan pada saat ini, terlebih negara kita telah ikut dalam upaya pembelaam HAM dalam dunia Internasional dan kita pun telah memiliki aturan normatif yang mencoba mengatur perlindungan HAM di negara ini. 
Hal di atas merupakan pergulatan politik hukum di dalam pembentukan pengaturan perlindungan anak di Indonesia, untuk memberi kepastian hukum terhadap perlindungan anak. Sebagaimana diuraikan di atas, politik hukum Indonesia adalah kebijakan yang ditetapkan penguasaan negara Indonesia mengenai hukum positif yang berlaku di Indonesia pada saat sekarang. Politik hukum perlindungan anak di Indonesia sebagai sistem hukum positif atau ius contituendum dan hukum yang diimpikan atau ius contitium yang berlaku dan yang akan berlaku pada saat sekarang dan pada masa akan datang. Sebab, sistem hukum perlindungan anak tersebut terbentuk sebagai konsekuensi penerapan politik hukum Indonesia. Dengan demikian, jika bertitik tolak dari uraian di atas jelas dapat dikemukakan, istilah politik hukum dan perlindungan anak di Indonesia, berkaitan dengan erat karena politik hukum Indonesia yang melahirkan sistem hukum Indonesia, ${ }^{23}$ yaitu sistem hukum perlindungan anak.

Undang-Undang Perlindungan Anak dibentuk sebagai hasil dari Politik Hukum Pemerintahan, di mana hal ini menjelaskan bahwa politik hukum bagian dari ilmu hukum yang mengkaji perubahan ius constitutum menjadi ius constituendum untuk memenuhi kehidupan perubahan masyarakat. Untuk memahami perubahan kehidupan masyarakat itu perlu ditelaah apakah pengertian perubahan, pengertian kehidupan, dan pengertian masyarakat.

\section{Analisis Perkembangan Pembentukan Perubahan Kedua Perlindungan Anak}

\section{Nomor 17 Tahun 2016}

Berkaitan dengan pembentukan Undang-Undang setelah Amandemen UUD 1945 dan sebelum maupun sudah ditetapkannya Undang-Undang Nomor 12 Tahun 2011 tentang Pembentukan Peraturan Perundang-Undangan, maka proses pembentukan Undang-Undang masih dihadapkan pada berbagai problematik, baik secara substansial maupun dari segi teknis yuridis penyusunan, maupun pelaksanaan dan penegakan hukumnya. ${ }^{24} \mathrm{Hal}$ ini juga berlaku dalam pembentukan perlindungan anak, sampai dengan disahkannya UU 17/2016, sebagai perubahan kedua atas Undang-Undang Perlindungan Anak.

Meskipun Undang-Undang Nomor 39 tahun 1999 Tentang Hak Asasi Manusia telah mencantumkan secara rinci tentang hak anak, namun pelaksanaan kewajiban dan tanggung jawab orang tua, keluarga, masyarakat dan Pemerintah untuk memberikan

Hotma Pardomuan Sibuea, Politik Hukum, Jakarta, Krakatauw Books, 2010, Hlm. 190.

24 Yuliandri, Membentuk Undang-Undang Yang Berkelanjutan, di dalam: Siti Sundari Rangkuti, Dinamika Hukum Tata Negara dan Hukum Lingkungan (Edisi Khusu Kumpulan Tulisan Dalam Ragka Purnabakti Pror. Dr. Siti Sundari Rangkuti SH), Surabaya, Airlangga University Press, 2008, Hlm. 281. 
perlindungan pada anak masih memerlukan suatu undang-undang mengenai perlindungan anak sebagai landasan yuridis bagi pelaksanaan kewajiban dan tanggung jawab tersebut. M. Junus Lamuda menyatakan sangat diperlukan pembentukan undang-undang ini didasarkan pada pertimbangan, bahwa perlindungan anak dalam segala aspeknya merupakan bagian dari kegiatan pembangunan nasional, khususnya dalam memajukan kehidupan bangsa dan negara. ${ }^{25}$

Sejatinya undang-undang yang berkaitan dengan perlindungan anak ini sudah ada pada tahun 1979 dengan keluarnya Undang-Undang nomor 4 Tahun 1979 tentang Kesejahteraan Anak. Undang-undang ini merupakan salah satu bentuk dari keprihatinan pemerintah terhadap perlindungan anak di Indonesia. Arif Ghosita ${ }^{26}$ menyatakan bahwa kesejahteraan anak adalah hak asasi anak yang diusahakan bersama. Pelaksanaan pengadaan kesejahteraan bergantung pada partisipasi yang baik antara objek dan subjek dalam usaha pengadaan kesejahteraan anak tersebut. Setiap anggota masyarakat dan pemerintah (yang berwajib) berkewajiban ikut serta dalam pengadaan kesejahteraan anak dalam suatu masyarakat yang merata akan membawa akibat yang baik pada keamanan dan stabilitas suatu masyarakat, yang selanjutnya akan mempengaruhi pembangunan yang sedang diusahakan dalam masyarakat tersebut. Oleh sebab itu usaha pengadaan kesejahteraan anak sebagai suatu segi perlindungan anak mutlak harus dikembangkan.

Di dunia Internasional instrumen hukum yang mengatur perlindungan hak-hak anak terdapat dalam konvensi Perserikatan Bangsa-Bangsa (PBB) tentang hak-hak anak (Convention on the Rights of the Child) tahun 1989, yang telah diravikasi oleh leboh dari 191 Negara. Pada tahun 1990 untuk lebih menghargai dan melindungi anak, maka pada tahun 1990 Indonesia melalui Keputusan Presiden Nomor 36 Tahun 1990 merativikasi Konvensi Hak Anak yang mengemukakan tentang prinsip-prinsip umum perlindungan anak, yaitu nondiskriminasi, kepentingan terbaik bagi anak, kelansungan hidup dan tumbuh berkembang dan menghargai partisipasi anak. Dengan demikian, Konvensi PBB tersebut telah menjadi hukum Indonesia dan mengikat seluruh warga negara Indonesia. ${ }^{27}$

Pada tahun 2002 pemerintah juga mengeluarkan Undang-Undang Nomor 23 Tahun 2002 tentang Perlindungan Anak (UU 23/2002), undang-undang ini dimaksudkan sebagai undang-undang payung (umbrella's law) yang secara sui generis mengatur hak-hak anak. Namun dalam konsiderans hukumnya justru tidak mencantumkan Konvensi Hak

25 Risalah Perundangan-Undangan Pembentukan Undang-Undang Nomor 23 Tahun 2002 Tentang Perlindungan Anak, Hlm. 19.

26 Arif Ghosita, Masalah-Masalah Perlindungan Anak, Jakarta, PT. Bhuana Ilmu Populer, 2004, Hlm. 35-36.

27 Rika Saraswati, Hukum Perlindungan Anak di Indonesia, Bandung, Citra Aditya Bakti, 2015, Hlm. 15. 
Anak (KHA) sebagai referensi yuridis. Sumber kesekahannya terletak pada landasan hukum rativikasi KHA yang menggunakan instrumen hukum keputusan presiden yang secara hierarki lebih derajatnya daripada undang-undang. Meskipun demikian, substansi KHA dapat diadopsi sebagai materi undang-undang, seperti penggunaan asas dan tujuan perlindungan anak yang di dalam undang-undang tersebut. ${ }^{28}$

Maidin Gultom menyatakan bahwa UU 23/2002 menjelaskan bahwa perlindungan anak adalah segala kegiatan untuk menjamin dan melindungi anak dan hak-haknya agar tetap hidup untuk menjamin dan melindungi anak dan hak-haknya agar tetap hidup, tumbuh, berkembang dan berpartisipasi secara optimal sesuai dengan harkat dan martabat kemanusiaan, serta mendapat perlindungan dari kekerasan dan diskriminasi. Perlindungan anak dapat juga diartikan sebagai segala upaya yang ditujukan untuk mencegah, rehabilitasi dan memberdayakan anak yang mengalami tindak perlakuan salah, eksploitasi dan penelantaran, agar dapat menjamin kelangsungan hidup dan tumbuh kembang secara wajar, baik fisik, mental maupun sosialnya. Perlindungan anak adalah suatu usaha melindungi anak agar dapat melaksanakan hak dan kewajibannya. ${ }^{29}$ Kebijaksanaan, usaha dan kegiatan yang menjamin terwujudnya perlindungan anak, pertama didasarkan atas pertimbangan bahwa anak-anak merupakan golongan yang rawan dan dependent, di samping itu, karena adanya golongan anak-anak yang mengalami hambatan dalam pertumbuhan dan perkembangannya, baik rohani, jasmani maupun sosial.

Dasar pelaksanaan perlindungan anak UU 23/2002 itu sendiri menurut Maidin Gultom adalah: ${ }^{30}$ a) dasar filosofis, Pancasila sebagai dasar kegiatan dalam berbagai bidang kehidupan keluarga, bermasyarakat, bernegara, dab berbangsa, dan dasar filosofis pelaksanaan perlindungan anak; b) dasar etis, pelaksanaan perlindungan anak harus sesuai dengan profesi yang berkaitan, untuk mencegah perilaku menyimpang dalam pelaksanaan kewenangan, kekuasaan dan kekuatan dalam pelaksanaan perlindungan anak; c) dasar yuridis, pelaksanaan perlindungan anak harus didasarkan pada UUD 1945 dan berbagai peraturan perundang-undangan lainnya yang berlaku. Penerapan dasar yuridis ini harus sesuai secara integratif, yaitu penerapan terpadu menyangkut peraturan perundangundangan dari berbagai bidang hukum yang berkaitan.

Perkembangan pengaturan perlindungan anak kembali mendapatkan angin segar pada tahun 2014, hal ini ditandai dengan pemerintah mengadakan perubahan dan

\footnotetext{
Ibid.

29 Maidin Gultom, Perlindungan Hukum Terhadap Anak dan Perempuan, Bandung, Refika Aditama, 2012 , Hlm, 70.

$30 \quad$ Ibid, Hlm, 70-71.
} 
penambahan terhadap UU 23/2002 melalui Undang-Undang nomor 35 Tahun 2014 tentang Perubahan Atas Undang-Undang Nomor 23 Tahun 2002 tentang Perlindungan Anak (UU 35/2014), yang telah berlaku sejak diundangkannya, yaitu pada tanggal 17 Oktober 2014. Penambahan substansi dalam UU 35/2014, di antaranya penambahan definisi kekerasan, perlindungan hak-hak anak dari segala bentuk kekerasan di satuan pendidikan, pemenuhan hak anak untuk tetap bertemu dan berhubungan pribadi dengan kedua orang tuanya setelah terjadi perceraian, larangan untuk memperlakukan anak secara diskriminatif dan segala bentuk kekerasan. ${ }^{31}$

Perubahan dan penambahan terhadap UU 23/2002 ini agar perlindungan anak selama ini belum dapat berjalan dengan aktif, karena masih adanya tumpang tindih antar peraturan perundang-undangan sektoral terkait dengan definisi anak. Di sisi lain, maraknya kejahatan terhadap anak di masyarakat, salah satunya adalah kejahatan seksual, memerlukan peningkatan komitmen dari pemerintah, pemerintah daerah dan masyarakat serta semua pengangku kepentingan yang terkait dengan penyelengaraan perlindungan anak. Untuk efektivitas pengawasan penyelenggaraan perlindungan anak diperlukan lembaga independen yang diharapkan dapat mendukung pemerintah dan pemerintah daerah dalam penyelenggaraan perlindungan anak.

Di dalam penjelasan UU 35/2014, menyebutkan bahwa perubahan ini mempertegas perlunya pemberatan sanksi pidana dan denda bagi pelaku kejahatan terhadap anak, untuk memberikan efek jera, serta mendorong adanya langkah konkret untuk memulihkan kembali fisik, psikis, dan sosial anak korban dan/atau anak pelaku kejahatan, Hal tersebut perlu dilakukan untuk mengantisipasi anak korban dan/atau anak pelaku kejahatan di kemudian hari tidak menjadi pelaku kejahatan yang sama.

Memang jumlah kekerasan pada anak khususnya kekerasan seksual terus meningkat. Terutama di tahun 2016 banyak sekali pemberitaan kekerasan seksual terhadap anak. Contohnya saja, anak diperkosa oleh orangtuanya, anak diperkosa oleh orangtua tirinya, anak diperkosa oleh saudaranya, anak diperkosa oleh keluarganya, anak diperkosa oleh temannya, bahkan anak perempuan diperkosa oleh beberapa orang yang melibatkan laki-laki dewasa ataupun laki-laki yang masih dikategorikan anak diabawah umur. Kondisi demikian mendorong banyak pihak, terutama para pemerhati perlindungan anak mendesak pemerintah untuk menerbitkan peraturan pemerintah pengganti undang-undang (Perppu) untuk mengubah undang-undang perlindungan anak. Presiden Joko Widodo pun merespon

31 Rika Saraswati, Op.cit, Hlm. 15-16. 
dengan cepat tuntutan tersebut dengan menetapkan Perppu Nomor 1 Tahun 2016 tentang Perubahan Kedua Undang-Undang Nomor 23 Tahun 2002 tentang Perlindungan Anak.

Rabu, 25 Mei 2016, Presiden Joko Widodo (Jokowi) telah menandatangani Perppu Nomor 1 Tahun 2016. Perppu yang sering disebut dengan Perppu Kebiri ini merupakan Perppu pertama yang dikeluarkan di masa Pemerintahan Jokowi, setelah lama diperdebatan. Sebagian pihak menyambut baik langkah Jokowi menerbitkan Perppu ini. Sebab hal itu dipandang sebagai bentuk keseriusan Pemerintah dalam hal mengatasi kondisi darurat kejahatan seksual terhadap anak. Terlebih kasus kejahatan seksual terhadap Anak di Indonesia dari hari ke hari semakin meningkat. Korban tidak hanya diperkosa, tetapi juga disiksa, dibunuh, bahkan dimutilasi. Oleh karena itu menurut Jokowi, kejahatan seksual pantas disebut sebagai kejahatan yang luar biasa (extraordinary crime). Sehingga membutuhkan penanganan khusus atau cara-cara kusus untuk mengatasinya. ${ }^{32}$ Salah satunya melalui pemberatan sanksi bagi pelaku dengan sanksi kebiri sebagai salah satu hukuman tambahan yang diatur dalam Perppu ini.

Perppu tersebut oleh Dewan Perwakilan Rakyat akhirnya disahkan. Perppu disetujui dalam sidang paripurna, pada tanggal 12 Oktober 2016, tanpa ada pengubahan isi. Namun, pengesahan ini disertai catatan. Fraksi Partai Keadilan Sejahtera dan Fraksi Partai Gerindra sempat menolak pengesahan Perppu menjadi undang-undang. Namun, setelah lobi pimpinan fraksi dan pimpinan DPR, PKS akhirnya menyetujui dengan catatan. Sedangkan Gerindra tetap dalam posisi menolak. ${ }^{33}$ Perppu tersebut menjadi undangundang Nomor 1 Tahun 2016 tentang perrubahan kedua Undang-Undang Nomor 23 Tahun 2002 tentang Perlindungan Anak (UU 1/2016).

Perppu ini mengubah dua pasal dari undang-undang sebelumnya, yakni pasal 81 dan 82, serta menambah satu pasal 81A. Berikut ini isi dari Perppu Nomor 1 Tahun 2016: Pasal 81 ayat (1) menyatakan bahwa setiap orang yang melanggar ketentuan sebagaimana dimaksud dalam Pasal 76D dipidana dengan pidana penjara paling singkat 5 (lima) tahun dan paling lama 15 (lima belas) tahun dan denda paling banyak Rp5.000.000.000,00 (lima miliar rupiah). Menjadi catatan, bahwa Pasal 76D Undang-Undang 23 tahun 2004 tentang Penghapusan Kekerasan Dalam Rumah Tangga (UU KDRT) menyatakan bahwa setiap orang dilarang melakukan kekerasan atau ancaman kekerasan memaksa anak melakukan

\footnotetext{
32 Zihan Syahayani, Problematika Perppu Kebiri, http://www.theindonesianinstitute.com/problematika-perppu-kebiri/, diakses pada tanggal 12 Juni 2017.

33 Kompas, Perppu Kebiri Disahkan DPR, Ini Aturan Barunya, http://nasional.kompas.com/read/2016/10/13/05300041/perppu.kebiri.disahkan.dpr.ini.aturan.barunya, diakses pada tanggal 12 Juni 2017.
} 
persetubuhan dengannya atau dengan orang lain. Sedangkan hukuman pidana pada UU KDRT sebelumnya adalah paling singkat tiga tahun dan paling lama 15 tahun. Adapun nominal denda sebelumnya berkisar Rp 60 juta hingga Rp 300 juta

Lebih lanjut Pasal 81 ayat (2) menyatakan ketentuan pidana sebagaimana dimaksud pada ayat (1) berlaku pula bagi setiap Orang yang dengan sengaja melakukan tipu muslihat, serangkaian kebohongan, atau membujuk Anak melakukan persetubuhan dengannya atau dengan orang lain. Pasal 81 ayat (3) Dalam hal tindak pidana sebagaimana dimaksud pada ayat (1) dilakukan oleh orangtua, wali, orang-orang yang mempunyai hubungan keluarga, pengasuh anak, pendidik, tenaga kependidikan, aparat yang menangani perlindungan anak, atau dilakukan oleh lebih dari satu orang secara bersama-sama, pidananya ditambah $1 / 3$ (sepertiga) dari ancaman pidana sebagaimana dimaksud pada ayat (1). Pasal 81 ayat (4) Selain terhadap pelaku sebagaimana dimaksud pada ayat (3), penambahan 1/3 (sepertiga) dari ancaman pidana juga dikenakan kepada pelaku yang pernah dipidana karena melakukan tindak pidana sebagaimana dimaksud dalam Pasal 76D. Pasal 81 ayat (5) Dalam hal tindak pidana sebagaimana dimaksud dalam Pasal 76D menimbulkan korban lebih dari 1 (satu) orang, mengakibatkan luka berat, gangguan jiwa, penyakit menular, terganggu atau hilangnya fungsi reproduksi, dan/atau korban meninggal dunia, pelaku dipidana mati, seumur hidup, atau pidana penjara paling singkat 10 (sepuluh) tahun dan paling lama 20 (dua puluh) tahun. Pasal 81 ayat (6) Selain dikenai pidana sebagaimana dimaksud pada ayat (1), ayat (3), ayat (4), dan ayat (5), pelaku dapat dikenai pidana tambahan berupa pengumuman identitas pelaku. Pasal 81 ayat (7) Terhadap pelaku sebagaimana dimaksud pada ayat (4) dan ayat (5) dapat dikenai tindakan berupa kebiri kimia dan pemasangan alat pendeteksi elektronik. Pasal 81 ayat (8) Tindakan sebagaimana dimaksud pada ayat (7) diputuskan bersama-sama dengan pidana pokok dengan memuat jangka waktu pelaksanaan tindakan. Pasal 81 ayat (9) Pidana tambahan dan tindakan dikecualikan bagi pelaku Anak.

Sedangkan tambahannya Pasal 81A ayat (1) menyatakan Tindakan sebagaimana dimaksud dalam Pasal 81 ayat (7) dikenakan untuk jangka waktu paling lama 2 (dua) tahun dan dilaksanakan setelah terpidana menjalani pidana pokok. Pasal 81A ayat (2) Pelaksanaan tindakan sebagaimana dimaksud pada ayat (1) di bawah pengawasan secara berkala oleh kementerian yang menyelenggarakan urusan pemerintahan di bidang hukum, sosial, dan kesehatan. Pasal 81A ayat (3) Pelaksanaan kebiri kimia disertai dengan rehabilitasi. Pasal 81A ayat (4) Ketentuan lebih lanjut mengenai tata cara pelaksanaan tindakan dan rehabilitasi diatur dengan Peraturan Pemerintah. 
Pasal 82 sebagai pasal tambahan, ayat (1) menyatakan setiap orang yang melanggar ketentuan sebagaimana dimaksud dalam Pasal 76E dipidana dengan pidana penjara paling singkat 5 (lima) tahun dan paling lama 15 (lima belas) tahun dan denda paling banyak Rp 5.000.000.000,00 (lima miliar rupiah). Tetapi bunyi pasal 76E dalam UU KDRT menyatakan bahwa setiap orang dilarang melakukan kekerasan atau ancaman kekerasan, memaksa, melakukan tipu muslihat, melakukan serangkaian kebohongan, atau membujuk anak untuk melakukan atau membiarkan dilakukan perbuatan cabul.

Lebih lanjut Pasal 82 ayat (2) menyatakan dalam hal tindak pidana sebagaimana dimaksud pada ayat (1) dilakukan oleh orang tua, wali, orang-orang yang mempunyai hubungan keluarga, pengasuh anak, pendidik, tenaga kependidikan, aparat yang menangani perlindungan anak, atau dilakukan oleh lebih dari satu orang secara bersama-sama, pidananya ditambah $1 / 3$ (sepertiga) dari ancaman pidana sebagaimana dimaksud pada ayat (1). Pasal 82 ayat (3) menyatakan selain terhadap pelaku sebagaimana dimaksud pada ayat (2), penambahan 1/3 (sepertiga) dari ancaman pidana juga dikenakan kepada pelaku yang pernah dipidana karena melakukan tindak pidana sebagaimana dimaksud dalam Pasal 76E. Pasal 82 ayat (4) menyatakan dalam hal tindak pidana sebagaimana dimaksud dalam Pasal $76 \mathrm{E}$ menimbulkan korban lebih dari 1 (satu) orang, mengakibatkan luka berat, gangguan jiwa, penyakit menular, terganggu atau hilangnya fungsi reproduksi, dan/atau korban meninggal dunia, pidananya ditambah $1 / 3$ (sepertiga) dari ancaman pidana sebagaimana dimaksud pada ayat (1). Pasal 82 ayat (5) menyatakan selain dikenai pidana sebagaimana dimaksud pada ayat (1) sampai dengan ayat (4), pelaku dapat dikenai pidana tambahan berupa pengumuman identitas pelaku. Pasal 82 ayat (6) menyatakan terhadap pelaku sebagaimana dimaksud pada ayat (2) sampai dengan ayat (4) dapat dikenai tindakan berupa rehabilitasi dan pemasangan alat pendeteksi elektronik. Pasal 82 ayat (7) menyatakan bahwa tindakan sebagaimana dimaksud pada ayat (6) diputuskan bersamasama dengan pidana pokok dengan memuat jangka waktu pelaksanaan tindakan, dan Pasal 82 ayat (8) menyatakan pidana tambahan dikecualikan bagi pelaku Anak.

Pasal 82A sebagai pasal tambahan menyatakan bahwa ayat (1) menyatakan tindakan sebagaimana dimaksud dalam Pasal 82 ayat (6) dilaksanakan selama dan/atau setelah terpidana menjalani pidana pokok. Pasal 82A ayat (2) menyatakan pelaksanaan tindakan sebagaimana dimaksud pada ayat (1) di bawah pengawasan secara berkala oleh kementerian yang menyelenggarakan urusan pemerintahan di bidang hukum, sosial, dan kesehatan. Pasal 82A ayat (3) menyatakan ketentuan lebih lanjut mengenai tata cara pelaksanaan tindakan diatur dengan Peraturan Pemerintah. 
Namun atas pengesahan, penjelasan dari pihak pemerintah masih kurang jelas terkait implementasi hukuman tambahan UU 1/2016 tersebut. Kalau pun harus setuju, maka catatan yang terpenting bahwa Perppu ini akan direvisi, maka harus dibuat undangundang yang lebih komprehensif dan bisa menjawab persoalan bangsa, khususnya anak dan perempuan. Hal ini agar kedepan tidak terjadi tumpang tindih terkait perlindungan anak, agar kepastian perlindungan anak semakin jelas dan semakin pasti didalam menjaga generasi penerus bangsa ini.

\section{PENUTUP}

\section{Simpulan}

Politik hukum dan perlindungan anak di Indonesia, berkaitan dengan erat karena politik hukum Indonesia yang melahirkan sistem hukum Indonesia, yaitu sistem hukum perlindungan anak. Pergulatan politik hukum di dalam pembentukan pengaturan perlindungan anak di Indonesia, adalah dampak dari untuk memberi kepastian hukum terhadap perlindungan anak. Politik hukum perlindungan anak di Indonesia sebagai sistem hukum positif atau ius contituendum dan hukum yang diimpikan atau ius contitium yang berlaku dan yang akan berlaku pada saat sekarang dan pada masa akan datang. Sebab, sistem hukum perlindungan anak tersebut terbentuk sebagai konsekuensi penerapan politik hukum Indonesia. Undang-Undang Perlindungan Anak dibentuk sebagai hasil dari Politik Hukum Pemerintahan, di mana hal ini menjelaskan bahwa politik hukum bagian dari ilmu hukum yang mengkaji perubahan ius constitutum menjadi ius constituendum untuk memenuhi kehidupan perubahan masyarakat. Untuk memahami perubahan kehidupan masyarakat itu perlu ditelaah apakah pengertian perubahan, pengertian kehidupan, dan pengertian masyarakat. Perubahan kedua Undang-Undang Perlindungan Anak 17 tahun 2016, menjelaskan bahwa perubahan undang-undang ini untuk menegaskan bahwa perlindungan anak dapat juga diartikan sebagai segala upaya yang ditujukan untuk mencegah, rehabilitasi dan memberdayakan anak yang mengalami tindak perlakuan salah, eksploitasi dan penelantaran, agar dapat menjamin kelangsungan hidup dan tumbuh kembang secara wajar, baik fisik, mental maupun sosialnya. Perlindungan anak adalah suatu usaha melindungi anak agar dapat melaksanakan hak dan kewajibannya. Namun atas pengesahan, penjelasan dari pihak pemerintah masih kurang jelas terkait implementasi hukuman tambahan UU 1/2016 tersebut. 


\section{Saran}

Adapun saran yang ingin penulis sampaikan adalah sebagai berikut: 1) Penulis berharap agar pihak pembentuk undang-undang yaitu pihak legislatif agar mengesahkan Perubahan Kedua Undang-Undang Perlindungan Anak akibat dari kebutuhan dinamika perlindungan anak, bukan karena ada kepentingan; 2) Penulis menyarankan agar Perubahan Kedua Undang-Undang Perlindungan Anak menjadi dasar penegak hukum dalam bertindak untuk penegakan hak-hak anak dan 3) Penulis menyarankan agar pemerintah membuat aturan yang lebih baik lagi terkait perlindungan anak, agar tidak terjadi tumpang tindih antar lembaga negara. 


\section{DAFTAR PUSTAKA}

\section{Buku}

Arif Ghosita, Masalah-Masalah Perlindungan Anak, Jakarta, PT. Bhuana Ilmu Populer, 2004.

Bintan Regen Saragih, Politik Hukum, Bandung, CV. Utomo, 2006.

Hotma Pardomuan Sibuea, Politik Hukum, Jakarta, Krakatauw Books, 2010.

J.H.A Logeman, Over de Theoroe Van Een Stellig Staatsrecht, Universitas Pers Leiden, (Penerjemah) Makkatutu, Tentang Teori Suatu Hukum Tata Negara Positif, 1976, Jakarta, Penerbit Ichtiar Baru-Van Hoeve, 1948.

Maidin Gultom, Perlindungan Hukum Terhadap Anak dan Perempuan, Bandung, Refika Aditama, 2012.

Mochtar Kusumaatmadja, Hukum, Masyarakat dan Pembinaan Hukum Nasional, Bandung, Bina Cipta, 1986.

Moh. Machfud MD, Pergulatan Politik dan Hukum Di Indonesia, Jakarta, Gramedia, 1999.

, Demokrasi Dan Konstitusi Di Indonesia, Studi Tentang Interaksi Politik Dan Kehidupan Ketatanegaraan, Jakarta, Rineka Cipta, 2003.

, Perdebatan Hukum Tata Negara Pasca Amandemen Konstitusi, Jakarta, Rajawali Press, 2010.

, Membangun Politik Hukum, Menegakkan Konstitusi, Rajawali Press, Jakarta, 2011.

, Politik Hukum di Indonesia, Jakarta, Rajawali Press, 2011.

Otong Rosadi dan Andi Desmon, Studi Politik Hukum, Suatu Optik Ilmu Hukum, Semarang, Thafa Media, 2012.

Rika Saraswati, Hukum Perlindungan Anak di Indonesia, Bandung, Citra Aditya Bakti, 2015.

Risalah Perundangan-Undangan Pembentukan Undang-Undang Nomor 23 Tahun 2002 Tentang Perlindungan Anak.

R. Abdussalam, Hukum Perlindungan Anak, Jakarta, PTIK, 2012.

Sunaryati Hartono, Politik Hukum Menuju Satu Sistem Hukum Nasional, Bandung, Alumni, 1991.

Apakah The Rule of Law Itu? Bandung, Alumni, 1976. 
Yuliandri, Asas-Asas Pembentukan Peraturan Perundang-Undangan Yang Baik, Gagasan Pembentukan Undang-Undang Berkelanjutan, Jakarta, Rajawali Press, 2010.

, Kerancuan Perumusan Norma Konstitusi, di dalam: Kelompok DPD RI, Jalan Berliku Amandemen Komprhensif (Dari Pakar, Politisi, Hingga Selebriti), Jakarta, Kelompok DPD RI, 2009.

, Membentuk Undang-Undang Yang Berkelanjutan, di dalam: Siti Sundari Rangkuti, Dinamika Hukum Tata Negara dan Hukum Lingkungan (Edisi Khusus Kumpulan Tulisan Dalam Ragka Purnabakti Prof. Dr. Siti Sundari Rangkuti SH), Surabaya, Airlangga University Press, 2008.

\section{Jurnal}

Yuliandri, Membentuk Undang-Undang Berkelanjutan, Jurnal Konstitusi Mahkamah Konstitusi Bekerjasama dengan Pusako, Volume 2, Nomor 2, 2009.

\section{Website/Internet}

Kompas, Perppu Kebiri Disahkan DPR, Ini Aturan Barunya, http://nasional.kompas.com/read/2016/10/13/05300041/perppu.kebiri.disahkan.d pr.ini.aturan.barunya, diakses pada tanggal 12 Juni 2017.

Zihan Syahayani,

Problematika

Регpри

Kebiri, http://www.theindonesianinstitute.com/problematika-perppu-kebiri/, diakses pada tanggal 12 Juni 2017. 